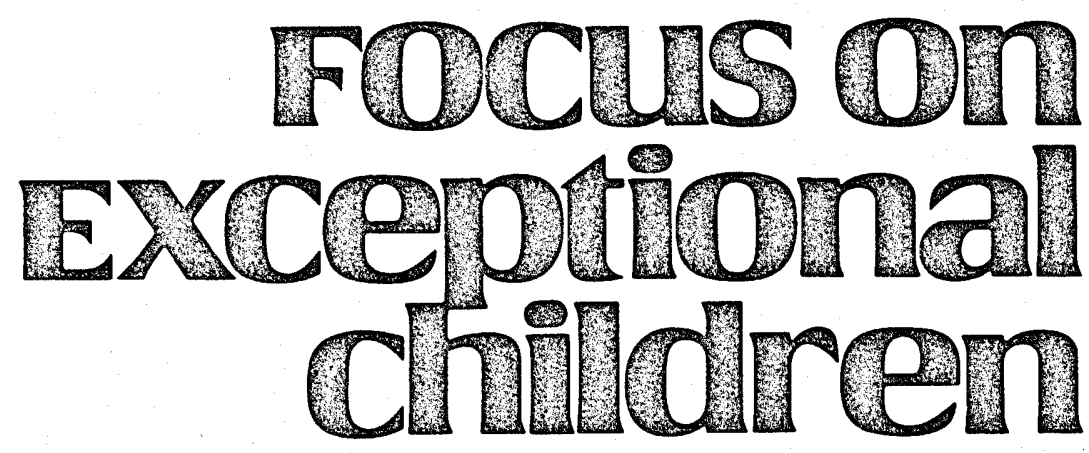

\title{
Mediation: A Common Sense Approach for Resolving Conflicts in Education
}

\author{
Randall F. Dobbs, Edith B. Primm, and Betsy Primm
}

Because education is such an integral part of American society, one can discern a great deal about the greater society from studying the educational microcosm. The 27 years since the landmark U.S. Supreme Court decision in 1954 in Brown v. the Board of Education of Topeka, Kansas (74 S.Ct. 686) offer clear evidence of this continuing truth.

Barely a generation ago a parent or a school system rarely considered suing one another in a court of law. Today, lawsuits have become so routine that the whole area of school law is fast becoming a specialty both for the plaintiffs and for the defense bar. Twenty years ago only a handful of cases involving children with disabilities had been decided. After passage of the Education for All Handicapped Children Act (Public Law 94-142) and its subsequent amendments [the latest being Public Law (PL) 101-476, the Individuals with Disabilities Education Act in 1990 (IDEA)], case law from states and from federal courts has mushroomed.

During this same time period in which special education law has been developing, American society has experienced a phenomenal increase in civil rights statutes and subsequent lawsuits defining those rights. The culmination of these civil rights statutes appeared with the passage of the Americans with Disabilities Act in 1990, affecting employment of people with disabilities throughout the United States. A statute effecting greater access to rights for American citizens carries under our system the concurrent right to procedural safeguards. These safeguards ensure that all those eligible for substantive rights are not arbitrarily or otherwise illegally denied access to them. Nevertheless, an increase in rights carries with it an increase in expectations and often an unclear understanding of exactly to whom the rights apply and in what way and under what circumstances these rights are to be applied. Concurrently, one person's right to an education or a job may directly impinge upon that same right of another person. Is such a situation right? Legal?

Knowing what is legal and what is right and, indeed, knowing whether it is in a person's best interest to pursue one or the other if they are not the same, can create conflict for an individual, a family, a group, or an entire organization. Knowledge of law both 
substantively and procedurally is no longer an option for most educators (whether administrator or teacher). Ignorance of the impact that conflicts involving these emerging rights may have on the quality of one's professional life can lead to negative results for teachers, administrators, students, and parents.

Conflict is a part of the human condition and an integral part of a dynamic, free society. Recognizing this fact, while learning some new ways to diminish the negative aspects of inevitable conflict, can lead to constructive resolutions based on stronger partnerships between individuals at all levels in schools and other organizations. Mediation is one of the most available of the constructive conflict resolution methods for educational settings.

\section{MEDIATION: WHAT IS IT?}

Mediation is a dispute resolution and collaborative problem-solving process that provides, in most cases, a trained impartial party who facilitates a negotiation process

\section{Focus on
Exceptional
childiren}

ISSN 0015-511X FOCUS ON EXCEPTIONAL CHILDREN (USPS 203-360) is published monthly except June, July, and August as a service to teachers, special educators, curriculum specialists, administrators, and those concerned with the special education of exceptional children. This publication is annotated and indexed by the ERIC Clearinghouse on Handicapped and Gifted Children for publication in the monthly Current Index to Journals in Education (CIJE) and the quarterly index, Exceptional Children Education Resources (ECER). It is also available in microfilm from Xerox University Microfilms, Ann Arbor, MI. Subscription rates: Individual, $\$ 27$ per year; institutions, $\$ 36$ per year. Copyright (C) 1991, Love Publishing Company. All rights reserved. Reproduction in whole or part without written permission is prohibited. Printed in the United States of America. Second class postage is paid at Denver, Colorado. POSTMASTER: Send address changes to:

$$
\begin{gathered}
\text { Love Publishing Company } \\
\text { Executive and Editorial Office } \\
1777 \text { South Bellaire Street } \\
\text { Denver, Colorado } 80222 \\
\text { Telephone (303) } 757-2579
\end{gathered}
$$

Edward L. Meyen

University of Kansas

Richard J. Whelan

University of Kansas Medical Center
Stanley F. Love
Publisher
Glenn A. Vergason Georgia State University

Holly T. Rumpler Senior Editor between parties who have reached an impasse. Mediation is structured but flexible, and is less formal and far less legalistic and intimidating than due process hearings or court proceedings. Although the parties are adversarial, mediation, unlike due process hearings, arbitration, or litigation, is nonadversarial.

"Adversarial" means against or opposed to one's interests, desires, and positions. This distinction between adversarial parties and processes is significant. The Ninth Annual Report to Congress on the Implementation of EHA (U.S. Department of Education, 1989) states the following regarding school personnel and parent satisfaction with the primary adversarial process used in resolving these type of educational disputes-the due process hearing:

Due process is considered ... to be an essential and necessary guarantee of the child's right to an appropriate educational program and the parent's right to challenge the recommendations of the school. On the other hand, however, as a result of its legal orientation, many parents and administrators who have participated in due process hearings consider hearings to be ill-suited to resolving educational disputes. Among the negative aspects reported by both groups are loss of control over decisions affecting the child [and] the developing of adversarial attitudes and tensions between school personnel and parents. [emphasis added] (p. 82)

Whether in matters of great political importance internationally, such as the Middle East hostage crisis, or domestically, such as the baseball strike, Eastern Airlines strike, or a free appropriate public education for handicapped students, an adversarial process to resolve disputes more often results in:

- polarization of positions.

- emphasis on right/wrong and win/lose solutions.

- orientation to past acts or omissions.

- rules of procedure.

- depersonalization.

- escalation of emotional and financial expenditures.

- restructuring of disputes to fit rules of the forum (administrative or court proceeding).

- reliance on a third party to make the decision.

- control of presentation of case in hands of others (attorneys, advocates) rather than the parties involved.

- control of the outcome in a third party (hearing officer, judge).

- less and increasingly hostile communication.

- dissatisfaction with the resolution by one or all parties. 
Mediation, on the other hand, is a nonadversarial collaboration process that often results in:

- discovery of mutual interests.

— joint problem solving.

- win/win solutions.

- orientation to the future.

- multiple options.

- creative, flexible solutions.

- respect for and sharing of differing expertise by parents and professionals.

- control of the process by a neutral mediator.

- control of the outcome in the hands of the parties involved instead of a neutral third party.

\section{GROWTH OF MEDIATION IN THE COMMUNITY AND SCHOOLS}

In 1977 the U.S. Department of Justice, under the leadership of Attorney General Griffin Bell, initiated a nationwide pilot project to experiment with various alternatives to litigation, such as mediation and arbitration. The Justice Center of Atlanta (JCA), formerly known as the Neighborhood Justice Center of Atlanta, was one of three pilot projects established to carry out this national experiment. The JCA chose mediation as the method it would employ in its efforts for the project.

During the first 18 months of the project (1978-1979), JCA settled more than 500 cases and handled some 1,200 referrals. Near the end of this 18-month period, Katheryn Bush, State Coordinator of the Georgia Learning Resource System (GLRS), requested that JCA undertake to provide mediation services and training for school personnel and parents involved in PL 94-142 disputes in Georgia. With initial funding from GLRS, a certification training program for mediators in such disputes was developed and taught by JCA. For several years the training was conducted at various sites around the state of Georgia for educators and parents who were encouraged to attend the same mediation course together. As a result, school systems and parents began to refer several cases a year directly to JCA. A few came from areas outside the metropolitan Atlanta area, but most were in the Atlanta area. No formal funding or school board policy was in effect to cover mediation services or cost in Georgia from 1979-1982, but the Code of Federal Regulations34 CFR 300.506, which details the procedural safeguards surrounding due process hearings required by Section 1415 (b)(2) of 20 U.S.C. (PL 94-142)-contains this comment:
Many states have pointed to the success of using mediation as an intervening step prior to conducting a formal due process hearing. Although the process of mediation is not required by the statute or these regulations, an agency may wish to suggest mediation in disputes concerning the identification, evaluation, and educational placement of handicapped children, and the provision of a free appropriate public education to these children. Mediations have been conducted by members of State educational agencies or local educational agency personnel who were not previously involved in the particular case. In many cases, mediation leads to resolution of differences between parents and agencies without the development of an adversarial relationship and with minimal emotional stress. However, mediation may not be used to deny or delay a parent's rights under this subpart.

Armed with this comment, which does not carry the force of law, Georgia school systems began encouraging mediation through JCA or through its own personnel trained by JCA when due process hearings were requested. In 1983, the Georgia State School Board adopted the following procedure involving mediation of special education matters:

Each local school system shall provide opportunity within the local system for concerned parties to mediate their differences in regard to the identification, evaluation, placement, and provision of a free appropriate public education to handicapped children. The parent is not required to participate in the mediation, but may decide to by-pass this process and request a hearing. Mediation will not interfere with the 20-day timeline from the time a hearing is requested. (Program for Exceptional Children, 1982)

It is believed that Georgia and JCA developed one of the first systematic, statewide procedures for mediation services in special education in the United States. To our knowledge, Georgia was the first statewide system involving a nonprofit, nonschool-affiliated outside provider along with state-trained personnel.

For the next 3 years the JCA's caseload of special education cases averaged eight per year. It is unknown how many mediation conferences were actually held by school personnel, as the state kept no formal documentation during that time. JCA believed that a significantly greater service could be provided around the state if funds for JCA's mediators' travel and small stipend could be found. Although the state, the local school systems, and parents who had used the process were favorable in their evaluation of the process, the numbers were too small and too concentrated in the metropolitan Atlanta area to warrant state funding. 
TABLE 1

Due Process Administrative Decisions in Georgia, 1984-1988

Action
Hearings scheduled
Administrative decisions
Civil action decisions
Complaints in administrative decisions/parents prevailed:
Eligibility/identification
Appropriate special education services
Related services
Placement
Procedural issues
Complaints in civil actions/parents prevailed:
Eligibility/identification
Appropriate special education services
Related services
Placement
Procedural issues

Does State collect data on attorney fees? (FYs 1987 and 1988 only) Attorney fees awarded (FYs 1987 and 1988 only)

\begin{tabular}{rrrrr}
\multicolumn{5}{c}{ Fiscal Years } \\
\hline 1984 & 1985 & 1986 & 1987 & 1988 \\
54 & 43 & 68 & 74 & 57 \\
31 & 27 & 43 & 33 & 19 \\
0 & 0 & 0 & 0 & 0 \\
& & & & \\
$10 / 3$ & $3 / 1$ & $8 / 0$ & $8 / 0$ & $4 / 0$ \\
$5 / 1$ & $17 / 1$ & $14 / 5$ & $20 / 3$ & $4 / 0$ \\
$2 / 1$ & $6 / 2$ & $6 / 0$ & $4 / 1$ & $0 / 0$ \\
$26 / 3$ & $17 / 4$ & $22 / 4$ & $26 / 6$ & $14 / 5$ \\
$0 / 0$ & $1 / 0$ & $9 / 2$ & $2 / 0$ & $12 / 1$ \\
& & & & \\
$0 / 0$ & $0 / 0$ & $0 / 0$ & $0 / 0$ & $0 / 0$ \\
$0 / 0$ & $0 / 0$ & $0 / 0$ & $0 / 0$ & $0 / 0$ \\
$0 / 0$ & $0 / 0$ & $0 / 0$ & $0 / 0$ & $0 / 0$ \\
$0 / 0$ & $0 / 0$ & $0 / 0$ & $0 / 0$ & $0 / 0$ \\
$0 / 0$ & $0 / 0$ & $0 / 0$ & $0 / 0$ & $0 / 0$ \\
& & & No & No \\
& & & \$ Unknown & \$ Unknown
\end{tabular}

Source: From Special Education, the Attorney Fees Provision of Public Law 99-372, General Accounting Office Briefing Report to Congressional Requesters, November 1989, Washington, DC: U.S. General Accounting Office.

JCA then sought and received a grant in 1985 from the William and Flora Hewlett Foundation in Menlo Park, California, to provide mediation services statewide for special education disputes. This grant will expire at the end of 1991. In the $5 \frac{1}{2} 2$ years of funding by the Hewlett grant, the special education caseload at JCA has grown from the average of eight per year to an average of 20. As of June 1991, JCA mediators have had 132 special education cases, with an agreement rate exceeding $70 \%$. In addition, cases have been referred from 46 counties instead of primarily from the 10 counties in the metropolitan Atlanta area.

The November 1989 General Accounting Office Briefing Report to Congressional Requesters, "Special Education, The Attorney Fees Provision of Public Law 99-372," details a rise from 31 to 43 due process administrative decisions in Georgia between 1984 and 1986. The same report, however, details a precipitous drop in the number of those same decisions from 43 in 1986 to 19 in 1988 (General Accounting Office, 1989). Table 1 reflects these data in more detail.

In an unpublished dissertation by L. G. Howard (1991) entitled "Incidents, Outcomes, and Fairness: An Analysis of Special Education Due Process Hearings in Georgia," this dramatic drop in the number of due process hearings in Georgia is also noted. The General Accounting Office Report for November 1989 concludes that the formal and informal settlement efforts under way across the nation are increasing the number of settlements prior to a formal due process hearing. At the same time, the report emphasizes that the number of hearing requests nationwide increased. This is a clear sign that mediation and other settlement activities are not interfering with due process rights.

While special education mediation has been growing, other uses of mediation to resolve matters such as disciplinary problems, peer arguments, parent and teacher conflicts, and administrator/administrator problems have been successful. A national organization, the National Association for Mediation in Education, continues to add to its membership and to influence students and school systems across the nation in the use of mediation. Now, more than 400 community-based, primarily nonprofit organizations like the JCA offer mediation to schools and the greater community for all types of disputes.

JCA has conducted training for statewide special education mediation services in 18 states and for the U.S. Department of Defense Overseas Dependents Schools and the U.S. Department of the Interior's Bureau of Indian Affairs Schools. A National Association of State Directors of Special Education (NASDE) survey (Sykes, 1989) of mediation training in the states is outlined in Table 2 . This study is slightly outdated but clearly indicates the significant commitment of many states to implementing mediation services into their conflict resolution options for special education disputes. 
TABLE 2

Survey of Mediation Training in the United States and Its Territories

\begin{tabular}{|c|c|c|c|c|}
\hline States & $\begin{array}{l}\text { Training } \\
\text { Required? }\end{array}$ & Preservice & Inservice & $\begin{array}{l}\text { Training } \\
\text { Source }\end{array}$ \\
\hline Alabama & No & - & - & - \\
\hline Alaska & Yes & $x$ & - & David Rostetter \\
\hline Arizona & Yes & $x$ & - & Terry David (IL SEA) \\
\hline Arkansas & Yes & $x$ & $x$ & - \\
\hline California & Yes & $x$ & - & $\begin{array}{l}\text { American Arbitrators } \\
\text { Assoc. }\end{array}$ \\
\hline Connecticut & Yes & $x$ & $x$ & $\begin{array}{l}\text { Gloria Symington } \\
\text { (CT SEA) }\end{array}$ \\
\hline Washington, DC & Yes & $x$ & $\mathrm{X}$ & "Gallant Model" \\
\hline Georgia & Yes & $x$ & $x$ & $\begin{array}{l}\text { Justice Center of } \\
\text { Atlanta }\end{array}$ \\
\hline Hawaii & No. & - & - & - \\
\hline Idaho & Yes & $x$ & - & $\begin{array}{l}\text { Justice Center of } \\
\text { Atlanta }\end{array}$ \\
\hline Illinois & Yes & $x$ & $x$ & - \\
\hline Indiana & Yes & $x$ & $x$ & Illinois SEA \\
\hline lowa & Yes & $x$ & $x$ & - \\
\hline Kentucky & Yes & $x$ & $x$ & $\begin{array}{l}\text { Justice Center of } \\
\text { Atlanta }\end{array}$ \\
\hline Louisiana & Yes & $x$ & - & $\begin{array}{l}\text { Justice Center of } \\
\text { Atlanta }\end{array}$ \\
\hline Maine & Yes & $X$ & $x$ & - \\
\hline Massachusetts & Yes & $x$ & $x$ & - \\
\hline Michigan & Yes & $x$ & $x$ & $\begin{array}{l}\text { SEMS Dir./Outside } \\
\text { Trainers }\end{array}$ \\
\hline Nevada & Yes & $x$ & - & Illinois SEA \\
\hline New Hampshire & Yes & $x$ & - & - \\
\hline New Jersey & Yes & $x$ & $x$ & SEA \\
\hline New Mexico & Yes & $x$ & $x$ & - \\
\hline North Carolina & Yes & $x$ & - & $\begin{array}{l}\text { Justice Center of } \\
\text { Atlanta }\end{array}$ \\
\hline North Dakota & Yes & $x$ & - & $\begin{array}{l}\text { Justice Center of } \\
\text { Atlanta }\end{array}$ \\
\hline Ohio & No & 一 & - & - \\
\hline Oklahoma & Yes & $x$ & - & South Atlantic RRC \\
\hline Oregon & No & - & - & - \\
\hline Pennsylvania & Yes & $x$ & $x$ & $\begin{array}{l}\text { Justice Center of } \\
\text { Atlanta }\end{array}$ \\
\hline Rhode Island & Yes & $x$ & - & - \\
\hline South Dakota & No & - & - & - \\
\hline Tennessee & Yes & $x$ & - & SEA \\
\hline Texas & Yes & $\mathrm{x}$ & $x$ & $\begin{array}{l}\text { Justice Center of } \\
\text { Atlanta }\end{array}$ \\
\hline Wyoming & Yes & $x$ & - & - \\
\hline Guam & No & - & - & - \\
\hline B.I.A. & Yes & $x$ & - & $\begin{array}{l}\text { Justice Center of } \\
\text { Atlanta }\end{array}$ \\
\hline
\end{tabular}

Source: From National Survey on Special Education Mediation Systems by D. Sykes, 1989, Washington, DC: National Association of State Directors of Special Education.
In Georgia the majority of assistant principals in two of the state's largest school systems-DeKalb and Fulton Counties-have taken mediator certification courses along with a number of classroom teachers in the past few years. The success of mediation in special education matters prompted the request from the training division of these two school systems for training its regular education personnel in the variety of disputes in which they are involved, including but not limited to special education matters. In 1990 the State Principals' Institute requested and received mediation training from JCA for its principals who attend their seminars from around the state.

Thus, the applications in special education and regular education, and in matters totally outside the realm of education, continue to grow as more and more people become exposed to and experienced with this common sense approach to conflict resolution. As we see the specific case applications and reports of benefits from mediation in the school setting, we are reminded that this growth in the field of education is truly a microcosm of the growing use of mediation in the world community.

\section{PARENTS AND MEDIATION}

Without question, one of the major intents of the Education of the Handicapped Act (now IDEA) was to give parents a voice in the design and content of educational programs developed for their children with disabilities. Though these laws specify the availability of due process hearings to address disagreements between parents and school systems involving special education issues, many parents-and many school systems-do not wish to invoke that due process right.

Mediation offers an alternative that is frequently more attractive to parents than formal due process hearings (Primm, 1988). The reasons parents have given for choosing to attempt to mediate disputes and concerns are wideranging. Among those most frequently stated are:

Speed. Mediation can often be scheduled in very short order because of the limited number of people usually involved in mediations and the nature of the process. Disputes and disagreements can often be addressed within a week of a request for mediation. Such immediate attention to concerns and disagreements helps keep the parties involved from escalating their issues into unresolvable matters.

Cost. Mediation of special education disputes is free to parents and school systems in Georgia. This service is 
made possible by a grant to the Justice Center of Atlanta from the William and Flora Hewlett Foundation of Menlo Park, California. Parents are often willing to exhaust this alternative prior to incurring the cost of retaining an attorney or beginning the potentially expensive and labor-intensive process of building a case to take to a formal hearing.

> Opportunity for full discussion of issues. Parents often report frustration, anger, and bitterness at what they perceive to be an educator's unwillingness to listen to their concerns. Mediation conferences allow all parties ample opportunity to fully discuss all issues, feelings, and concerns that are important to them. Because the legal "rules of evidence" do not apply to mediation, parents can deal with whatever matters concern them, regardless of whether they might be judged irrelevant or immaterial in other settings such as due process hearings. Being heard and really listened to is often a paramount issue with parents who are at odds with school system personnel.

- Fearldistrust of school personnel. Mediation offers parents and school personnel the opportunity to sit down with a neutral third party whose role is to help facilitate a mutually satisfactory resolution of the matters concerning them. If the mediator is not an employee of the school system with which the parent has a dispute, the parent's perception of the neutrality and objectivity of mediation increases. Parents are often willing to spend time working with a third-party mediator whom they perceive as objective, in hopes of resolving the problems they are experiencing or are concerned about in regard to their child's education.

- Maintenance of a workable relationship with school personnel. One of parents' greatest fears in bringing a formal complaint or hearing against personnel is that their child will be punished or will suffer because of retaliation by school employees. Though this fear is based on emotion rather than fact, it is nonetheless very real. Parents and school personnel view mediation as a way to deal with major concerns while minimizing the perceived likelihood of ending an ongoing working relationship and instead directing attention toward benefiting the student with disabilities, who is the focus of their mutual concern.

- Perception of nothing to lose. Because mediation cannot delay the timelines established for due process hearings and cannot interfere with any of the due process rights accorded either by federal statute or by state regulations, many parents are willing to participate in the process. They may do so because they genuinely hope to come to a settlement or simply because they want to hear what the other side's arguments are so they can be better prepared for a due process hearing.

Regardless of parents' motivations to attempt mediation, their coming to the conference establishes an opportunity to settle issues and build a framework for future cooperation between the disabled student's family and the school personnel involved with the student's education.

\section{PARENT AND SCHOOL RESPONSES TO MEDIATION}

The parties involved in the mediation process, irrespective of the outcome, tend to view it as worthwhile. In a follow-up survey of the parties involved in 58 special education mediation cases conducted by the Justice Center of Atlanta, 20 of the 30 parents $(66.5 \%)$ responding to it and 37 of 51 of the personnel (72\%) responding for the school systems involved stated that the mediation conference either partially or completely resolved their dispute. Further, 28 of the 30 parents (93\%) and 49 of the 51 school system $(96 \%)$ responses to the survey stated that they would recommend the use of mediation to others (Primm, 1988). This finding indicates that the process itself benefits those who choose to engage in it.

If mediation conferences do not result in satisfactory resolution of the disputed issues, the parties involved still have all of their due process rights available to them should they choose to exercise them. When mediation conferences result in partial or total resolution of conflicts and disputes between parents and school system personnel, all parties tend to be potentially well served because they were all involved in the process and in drafting and approving the terms of the agreement. Therefore, they all have an investment in its successful implementation.

Conflicts between parents and school personnel unfortunately tend to lead to a lack of trust among the parties involved. Only time and an opportunity to evidence good faith effort in putting into effect the terms of a mediated agreement can build or restore a positive working relationship between parents and educators. Both the process of attempting mediation and the actions of the parties subsequent to mediation conference have a major influence in determining whether and to what degree a working relationship is established and ultimately redounds to the disabled child's educational benefit. 


\section{SCHOOLS AND MEDIATION}

While mediation is a viable alternative to the formal due process hearing, it has numerous, more informal applications in the local school system. Conflict is not restricted to the due process hearing dispute and emerges in all aspects of school life: parent to school, teacher to teacher, student to student (discipline), administrator to administrator, administrator to teacher, and even parent to child. Three of the four following case studies illustrate the use of mediation at a more informal level. (The process is often used by trained mediators, who are school personnel, without calling it formal mediation.) The fourth illustrates its use formally.

\section{JCA Case Study: Parent and Child}

Jason's appearance would lead you to be believe he was a normal fourth-grade boy. Any observation, however, would soon allow you to know that he was teetering on the brink of disaster. In recent months he had been seriously withdrawn, totally unable to concentrate on his work, and generally unable to cope with any aspect of school. Because of his long history of "slow" academic work and recent emotional problems and increased truancy, he had been referred to the local school's Student Support Team (SST). Alternative strategies were tried for many weeks with no success.

In recent weeks Jason had started to skip school altogether. He began his truancy by being absent on Mondays and Fridays, but soon it was not uncommon for him to go a full week without showing. A social work referral only turned up frustrated parents who knew that Jason needed to be in school. They seemed powerless in curbing his growing truancy problem. Mom worked the 7:00 a.m. to 3:00 p.m. shift at a printing company, and dad worked the midnight to 9:00 a.m. shift at a local factory. Because of the work schedules of Jason's parents, no one was available to push him out the door in the morning.

Jason's teachers and the principal decided to call his parents every day to report his absence. The parents were truly concerned, and when their employers would permit, one or the other would leave work to go and bring Jason to school. That strategy quickly failed because the employers docked their pay, as both parents were wage-per-hour employees.

The school psychologist evaluated Jason and found him to be school phobic. After further testing, Jason was plac ed in a special education program to address his academic and emotional needs. Jason's parents and the school per- sonnel believed the program was well designed and would surely meet his needs. Jason, however, still refused to come to school.

The principal worked out a plan with Jason's parents that would allow him to go to Jason's home and physically take him to school. The principal had no idea the adventure on which he was about to embark. Though "handicapped," Jason was incredibly ingenious. The principal met many obstacles that Jason placed in his way. The principal chased him through the crawl space of the house, prepared his breakfast, found clothes for him to wear, and one time even talked him into coming down from the top of a tree! Once Jason was at school, he did reasonably well, but getting him there was an ongoing battle of wits.

On a cold, rainy morning after an encounter that had resulted in muddy clothing to both, the principal and Jason sat quietly as they drove to school. At that point, neither was particularly interested in talking or going to school. The principal began the conversation with the usual question: "Jason, why don't you want to come to school?" But today was to be different; Jason was going to tell him.

Jason's parents had been experiencing marital problems for months and on numerous occasions fought while they thought Jason was sound asleep in his bedroom. Jason heard the blow-by-blow description of how each threatened to leave the marriage. His father's usual threat was to come home from work, pack his bags, and leave.

As Jason emotionally related the story, the principal realized the horrendous responsibility Jason had assumed. Jason's theory was not sophisticated: If he could be home when his father returned from work, he could stop him from leaving. Even though Jason's parents had been careful to fight "out of his sight," he knew the day and the time he had to be on duty. Jason had transferred to himself the burden of keeping the family from breaking up. While not happy about the responsibility, he had assumed it nobly!

The principal pulled slowly off the road and stopped the car. He turned to Jason and attempted to summarize the pain and responsibility he perceived that Jason had taken on. Jason dropped his head and cried.

Upon returning to school, the principal promised to help Jason. In one sense Jason seemed sad, but in another he seemed relieved. As the principal pondered a plan, he knew that informal mediation between Jason and his parents would provide a forum for attempting to solve the complicated issues and relieve Jason of his self-induced responsibility. The principal called both parents and, without telling them his findings, insisted that they be in his office at 3:30 that afternoon. 
In a brief meeting with Jason before his parents' arrival, the principal explained how the meeting was to unfold. When all had assembled, the principal observed the participants carefully. The parents seemed puzzled by the command performance and quietly asked if Jason was in trouble. Jason sat quietly staring at the floor. The principal tried to put everyone at ease by simply saying he had learned a great deal that day and wanted to see if a plan could be developed that would help Jason come to school every day.

He then asked Jason to relate the story he had told the principal that morning. With great reluctance and prompting from the principal, Jason slowly explained his fears and how much he did not want his daddy to leave their home. Surprisingly, he even quoted his father: "I'm going to come home tomorrow morning and pack my bags."

When Jason ended his laboriously told story, the principal asked him one question: "Do you think if you are home each morning, you can stop your father from leaving?" Jason tearfully responded "yes." Jason's parents sat quietly and stared at the floor.

The principal asked the parents to explain to Jason how they saw the situation. Each in turn explained that things between them were difficult and that they might soon separate. Without prompting, they both said how much they loved Jason and even if they did split, they would continue to love him, and the problems they had were in no way related to him. Jason showed no visible relief.

When the parents had finished their story, the principal met with Jason privately and then privately with the parents. Upon reconvening, the principal asked if they could all agree on anything that would help the situation. After a lengthy discussion, the following is the essence of the agreement the principal wrote down for them.

1. Mom and Dad agree that they love Jason more than anything else and want him to be successful in school.

2. Jason agrees that he loves his parents very much and really does want to come to school.

3. Mom and Dad acknowledge to Jason that they are having marital difficulties and that they may choose to separate in the near future.

4. Mom and Dad promise that if they do separate, they will discuss the plan with Jason in advance and that he will have at least 24 hours' notice before his father leaves.

5. Dad promises that if he leaves, he will not leave during the school day and that he will talk to Jason before he leaves.

6. Jason agrees to come to school every day that he is not ill and to work hard in school.
Jason and his parents signed the agreement, and the principal witnessed it. Everyone left the office with a newfound peace and understanding. Jason carried his agreement in his back pocket for many weeks.

Jason's attendance at school turned around remarkably. He continued to have learning problems but was making definite progress. Within a few months, Jason's parents decided to separate. They discussed the plan with Jason on a Saturday morning; Dad left on the following Sunday afternoon.

Although the split of Jason's parents would never be easy for him, the responsibility for trying to keep it from happening was a burden he simply could not carry. The process of mediation relieved him of that responsibility and allowed him to return to school.

\section{JCA Case Study: Student and Student}

Billy was a strong, handsome seventh-grade boy who had spent most of his educational career in the behavior disorders (BD) program. He was prone to taking matters into his own hands, which usually resulted in violence. He seemed to be one of those really good, likable kids who just couldn't keep it all together for any length of time. He had a short fuse, and everyone knew it.

David was a well-liked boy in the same grade, with almost opposite characteristics. He was short and slight of build, but he made up for his size with a quick wit and good intellect. Unpredictably, David and Billy had become the best of friends-which often resulted in the worst of enemies. Their antics and escapades often ended in David's teasing Billy. David knew all the right buttons to push. The result was usually a fight. David could get the best of Billy in the teasing, but Billy could clearly win the challenge when he took matters into his own hands.

Both students had visited the principal on several occasions for fighting and related matters. The traditional detention-in-house suspension and out-of-school suspensionhad been attempted to encourage acceptable behavior. But both students seemed to find their punishment worth the pleasure of their crime!

On the next occasion of the boys' fighting, the principal decided to use mediation to try to curtail their unacceptable behavior. At first the boys were unsettled, not serious about the process, and considered it a game. But the principal seized their attention when he told them that if they were not able to work out a satisfactory resolution to their problem, he would (in another meeting) assume the responsibility and pursue the problem through the most serious process in the system: the board disciplinary tribunal. 
Although the boys were basically good kids, their repeated violations made them subject to more serious procedures. The seriousness with which the boys returned to their task of negotiations increased dramatically.

After a reasonably short time, the boys drafted the following agreement to attempt to resolve their problems:

1. Billy and David agree that fighting is not a satisfactory way to resolve their differences.

2. The boys agree that their friendship is important and that they will make efforts to find an acceptable solution.

3. David agrees that teasing Billy is not in the best interest of their friendship and that he will find a more productive way of expressing himself.

4. Billy agrees not to use violence as a means of resolving their differences.

5. Both boys agree to ask an adult for help before the situation gets out of hand.

A few incidences occurred during the remainder of the year, but the fighting between Billy and David was greatly reduced. They immensely enjoyed the process of mediation and often bragged to other students that they had a written agreement to "guide" their actions. On several occasions, as other students faced the principal for disciplinary action, they would request the opportunity to try mediation.

Mediation as a tool in the discipline process is often perceived as being slow and cumbersome, but the payoff of students' taking responsibility for their own actions and planning tactics to address problems is far-reaching. The ideas and strategies they are able to generate often outweigh the time invested in the process.

\section{JCA Case Study: Teacher and Teacher}

Working on a team can be one of the most rewarding work experiences or it can be the source of tremendous conflict. The teachers of the "A Team" had known both, and most recently the conflict was destroying their ability to function. It had become so bad that even the second-grade students in the unit knew when the teachers had had words.

The teachers were disagreeing over whether to use the teaching strategy "precision teaching" in their reading program. All had been trained in it as a function of their special education department. Though all agreed that the strategy had great value, the opponents argued that it was too time-consuming to use with larger class instruction. The battle was joined in the classroom, the cafeteria, the playground, the teachers' lounge-and it finally demanded the principal's attention. When the principal became involved, the positions were entrenched and the teachers were unwilling to give an inch.

After the first meeting to attempt to resolve the dispute, the teachers voiced their frustration and demanded that the principal make a decision declaring one group the "winner." The principal recognized the great strength of all the teachers and was seriously concerned about damage control. If one group "lost," would they lose their enthusiasm for their work? Would they no longer be able to work together as a team? They were clearly the strongest team in the school and were also the most progressive thinkers. Their positions were strong and solid.

After giving the teachers an appropriate amount of time to solve the problem themselves, the principal scheduled a meeting with the team and informed the members in advance that he would act as a mediator. Each group was instructed to come to the table with its best plan to convince the other side of its position.

After numerous sessions, a written agreement was reached that allowed both sides to preserve (and give up) parts of their plan. The agreement included the following:

1. Both sides of the Precision Teaching debate acknowledge that the A Team teachers have good arguments supporting their positions.

2. Each side recognizes that the conflict in which they are embroiled is damaging to their day-to-day ability to function and that a suitable resolution must be implemented to preserve their team approach.

3. Precision Teaching will be used in the unit in the following manner:

a. Reading groups with six or fewer students.

b. Reading groups that contain at-risk and handicapped students and are five or fewer students in number.

4. For groups with more than six students (or do not satisfy $3 b$ ), the regular adopted reading program will be used with its prescribed teaching strategies.

5. All A Team teachers agree that this plan will be followed until the end of the year and that the plan will be evaluated and a new plan developed for next year.

Even though the agreement seems simple in some ways, it provides a powerful resolution to a damaging situation. The benefits of using mediation to resolve this conflict are:

The process allowed the teachers to disagree professionally in a forum that preserved and protected their present and future relationship. 
- They learned more about each other's positions by carefully designed listening.

- A compromise was reached that promoted peace and a win/win situation.

- Members of the team had a greater respect for each other and the administrator for being able to work through their own problems.

$>$ The team chose to continue working together in future years.

\section{JCA Case Study: Parent and School System}

In 1987 Georgia initiated a major push to relocate students with severe physical and mental handicaps from training centers run by the state health department to the local school programs. Heretofore, these students had been receiving educational services at the training center, either from their appropriate staff or itinerant teachers from the local school system. Advocacy groups, as well as state and local school officials, took the position that appropriate placement for many of these students was in the local school system. Many parents, however, had come to be comfortable with the training center placements, where they felt their children were well treated and programs were being well implemented. In addition, many parents worked fulltime, and a longer day program-usually from 7:30 a.m. to $4: 30$ p.m. - was available at the training centers but not in the local school system programs.

In May 1987, the Justice Center received a call from a local school system's director of special education regarding a dispute over placement of a student with severe mental and physical disabilities. This student was to be moved from a training center and placed in the local elementary school for the fall term beginning the next September. The student, Amy, was chronologically 9-years old, but neurologically around 6 months of age.

Even more important to the dispute, Amy's medical condition was so fragile that she had spent 6 of the past 9 months of the school year in and out of the hospital. The slightest cold or sore throat was life-threatening. Resuscitation equipment was kept at the training center, and the paramedics had been called on four or five occasions during the past school year. The local school system was anxious about having Amy in its elementary school program, but it was prepared to take Amy because her education was their responsibility under their present understanding of federal and state guidelines and the developing case law. The staff had been trained in resuscitation, and equipment was in place at the local elementary school.
When the parents were notified of the IEP meeting, they attended but refused to agree to the change in placement. The local school system asked for a mediation conference, and the parents assented. The Justice Center agreed to supply the mediator, and the conference was held at the central office of the local school system.

The school personnel felt they were being placed in a position of either being forced to violate what they understood to be their legal responsibility and thereby jeopardize their funding or to file for a due process hearing, which they did not want to do. The school officials and the parents had had a warm working relationship, and the school personnel were well aware of the extreme financial and emotional difficulties this family had been through for 9 years. They admired the family's courage and fortitude and did not want to add a due process hearing to their burdens. They could not, however, just let it go.

In addition, the mother was a valued employee of the training center. She was a bus driver and would be difficult to replace. They feared that the health department employees at the training center would blame them if the mother decided to quit as a result of the school system's having pursued a due process hearing against her.

On top of everything else, this situation would do little to help emerging interagency agreements! The school system and parents were on the horns of a dilemma.

The mediation conference was held, and it lasted the better part of 6 hours. The director of special education, an assistant superintendent, and the proposed classroom teacher, who was trained in using emergency techniques and resuscitation equipment, represented the school system. The mother and father, along with the maternal grandmother, attended on Amy's behalf.

The three family members presented their position with great anguish. Their view was that if they allowed this placement, even experimentally, Amy would probably die. Their fears were based on Amy's frequent and recent lifethreatening emergencies in the more protected environment of the training center, which had fewer children as well as highly skilled staff with personal experience in handling Amy's crises.

The local school system understood the family's concerns and fears. They tried their best to reassure the family regarding the highly trained staff and advanced equipment the school had ready to meet Amy's needs. The parents reiterated that they had no interest in educational programs or what the school system thought it could do. Amy's survival and hoped-for improvement in quality of life was all that mattered to them. The school system explained that it 
agreed with the family's priorities and stated that these factors would be their primary goals for Amy during the next school year.

As the mediation progressed, it became clear to the mediator that everyone at the table was concerned with Amy's physical health and safety. Each person realized that if the school system did not prove to be as capable of handling Amy as it believed and the evidence strongly suggested it was, the results could be disastrous. Amy might die. In a caucus (the private meeting of the mediator with each side in a dispute) with the parents, the mediator asked to review one more time a doctor's letter regarding Amy's condition. The mediator asked the parents if, as a result of Amy's fragile health, they would consider any placement other than the training center. The mediator asked for their views about a homebound teacher.

After much discussion and thought, the parents said homebound service would certainly be preferable to the classroom in the local school. If the training center was no longer an acceptable placement even for students as fragile as Amy because of the developing case law and other pressures for mainstreaming, the parents would accept homebound instruction as an appropriate placement. They stated that they would never accept the local school system placement while Amy was in her present fragile condition. This plan was made even more feasible when the grandmother volunteered to care for Amy while her mother was driving the training center bus in the mornings and the afternoons.

When this alternative, and the parents' acceptance of it, was presented to the local school system personnel for their consideration, they readily agreed and immediately suggested that a homebound teacher come three times weekly for an hour per visit. The parents agreed to that schedule, and the mediator asked all the parties for their help in writing up the agreement to accurately reflect these terms. The agreement was to be presented as their joint recommendation at the IEP meeting, which was to be convened as soon as possible.

As the mediator was leaving the conference, the director of special education noted that everyone necessary to constitute an IEP meeting was present. She suggested that they convene an IEP committee meeting in 15 minutes to review the mediated agreement if the parents were willing. All parties agreed that this made sense, and the IEP meeting was held. Although IEP meetings seldom take place this quickly after a mediation, it can be done when the circumstances are appropriate, as in this case. The IEP committee accepted as appropriate the joint recommendations in the mediated agreement.
Amy received homebound instruction for one year and entered the local school system class the following September. She and the local school system staff have adjusted well, although Amy still has serious medical difficulties at times. Amy's parents have continued to work with the school system as they try to provide for Amy's special education and health-related needs.

\section{CONCLUSION}

These results and case studies offer evidence that the common sense approach of using mediation in school settings is worth the time and effort. The opportunities emerging for handicapped students and those who work with them will be limited unless efforts to balance competing rights and interests are adopted and implemented. Mediation provides a common sense mechanism to accomplish this task.

\section{REFERENCES}

General Accounting Office Briefing Report to Congressional Requesters. (1989, November). Special education, the attorney fees provision of Public Law 99-372. Washington, DC: GAO.

Howard, L. G. (1991). Incidents, outcomes, and fairness: An analysis of special education due process hearings in Georgia. Unpublished doctoral dissertation, Georgia State University, Atlanta.

Primm, E. B. (1988). Mediation of school disputes in Georgia: Survey and analysis. Atlanta: Justice Center of Atlanta.

Program for Exceptional Children. (1982). Procedures of the Georgia Department of Education: IDDFd3-2E, Hearing Process, Local Mediation 1. Atlanta: Georgia Department of Education.

Sykes, D. (1989). National survey on special education mediation systems. Washington, DC: National Association of State Directors of Special Education.

U.S. Department of Education. (1989). Ninth Annual Report to Congress on the Implementation of EHA. Washington, DC: U.S. Government Printing Office.

\section{ADDITIONAL REFERENCES}

Primm, E. B. (1990, June). Mediation: A comment under Part B; common sense for Part H. Early Childhood Report, l(6), 4-6, 12.

Primm, E. B., Dobbs, R. F., Primm, B., et al. (1982). Dispute resolution in education: The NJCA mediation model. Atlanta: Neighborhood Justice Center of Atlanta, Inc. 


\section{Professional update}

October 10-12, 1991

Council for Learning Disabilities

Annual Conference

Minneapolis, Minnesota

Contact: (913) 492-8755

\section{November 10-12, 1991}

Council for Exceptional Children

Conference on At-Risk Children and Youth

New Orleans, Louisiana

Contact: CEC, 1920 Association Drive Reston, VA 22091
November 14-17, 1991

National Early Childhood Conference

on Children with Special Needs

St. Louis, Missouri

Contact: CEC, 1920 Association Drive Reston, VA 22091

November 21-22, 1991

Association for Persons with Severe Handicaps

Annual Conference

Washington, D.C.

Contact: TASH, 7010 Roosevelt Way NE, Seattle, WA 98115

\section{PERMISSIONS AND COPYRIGHT}

All rights are reserved. No part of this publication may be reproduced, photocopied, faxed, stored in a retrieval system, or transmitted, in any form or by any means, electronic, mechanical, recording or otherwise, without the prior written permission of the publisher.
Back issues are available for sale. Reproduction requires permission and payment of fees. It is illegal and a violation of Federal copyright law to reproduce this publication without permission. Direct all inquiries to the permissions editor. 